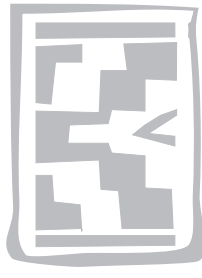

\title{
Evaluation of a rapid immunodiagnostic test kit for detection of African lyssaviruses from brain material
}

\author{
W. MARKOTTER ${ }^{1}$, D. YORK ${ }^{2}$, C.T. SABETA ${ }^{3}$, W. SHUMBA ${ }^{3}$, G. ZULU ${ }^{3}$, K. LE ROUX ${ }^{4}$ \\ and L.H. NEL ${ }^{1}$
}

\begin{abstract}
MARKOTTER, W., YORK, D., SABETA, C.T., SHUMBA, W., ZULU, G., LE ROUX, K. \& NEL, L.H. 2009. Evaluation of a rapid immunodiagnostic test kit for detection of African lyssaviruses from brain material. Onderstepoort Journal of Veterinary Research, 76:257-262

A rapid immunodiagnostic test kit was evaluated against a selection of isolates of lyssavirus genotypes occurring in Africa. The test was carried out in parallel comparison with the fluorescent antibody test (FAT) and isolates representing previously established phylogenetic groups from each genotype were included. The specificity of the rapid immunodiagnostic test compared favourably with the FAT and was found to detect all representatives of genotypes 1, 2, 3 and 4 in brain samples of either field cases or suckling mouse brain inoculates.
\end{abstract}

Keywords: Africa, diagnostics, lyssavirus, rabies, rapid test

\section{INTRODUCTION}

Rabies is caused by all members of the lyssavirus genus in the family Rhabdoviridae of the order Mononegavirales, a group of single stranded negative sense RNA viruses currently consisting of seven genotypes (gts). Classical rabies viruses (RABV) are grouped in the lyssavirus genotype 1 (gt 1) and occur worldwide (Tordo, Benmansour, Calisher et

* Author to whom correspondence is to be directed. E-mail: wanda.markotter@up.ac.za

1 Department of Microbiology and Plant Pathology, University of Pretoria, Pretoria, 0002 South Africa

2 Molecular Diagnostic Services, Private Bag X20, Westville, Durban, Kwazulu Natal, 3630 South Africa

3 OIE Rabies Reference Laboratory, Onderstepoort Veterinary Institute, Private Bag X05, Onderstepoort, 0110 South Africa

4 Allerton Veterinary Laboratory, Private Bag X2, Cascades, Pietermaritzburg, 3202 South Africa

Accepted for publication 1 July 2009-Editor al. 2004). Two biotypes of RABV occur in Africa; the mongoose biotype and the canid biotype (Von Teichman, Thomson, Meredith \& Nel 1995; Nel, Sabeta, Von Teichman, Jaftha, Rupprecht \& Bingham 2005). In addition, gt 2 (Lagos bat virus (LBV)), gt 3 (Mokola virus (MOKV)) and gt 4 (Duvenhage virus (DUVV)) have been reported exclusively from the African continent (Nel \& Markotter 2007). There is little surveillance for these gts but all have been reported from South Africa and other African locations in recent years (Paweska, Blumberg, Liebenberg, Hewlett, Grobbelaar, Leman, Croft, Nel, Nutt \& Swanepoel 2006; Markotter, Kuzmin, Rupprecht, Randles, Sabeta, Wandeler \& Nel 2006a; Markotter, Randles, Rupprecht, Sabeta, Wandeler, Taylor \& Nel 2006b; Sabeta, Markotter, Mohale, Shumba, Wandeler \& Nel 2007; Kuzmin, Niezgoda, Franka, Agwanda, Markotter, Beagley, Urazova, Breiman \& Rupprecht 2008). The gold standard for lyssavirus diagnostics approved by both the World Organization for Animal Health (OIE) and the World Health Organization (WHO) (WHO 2005), the fluorescent antibody test 
(FAT) (Dean, Abelseth \& Atanasiu 1996), is performed on brain tissue. These preparations are stained with anti-lyssavirus serum (conjugate) labelled with fluorescein isothiocyanate (FITC) and viewed under a fluorescence microscope. This test therefore cannot be performed under field conditions since specialized equipment is needed.

It is important that rabies diagnosis be quick and reliable in order to ensure correct post exposure prophylaxis (PEP) decisions and prevent fatal infections in cases of human exposures. Diagnostics in epidemiological studies aimed at prevention and control of the disease in the relevant reservoir species should also be as practical as possible. Routine diagnostic tests should focus on brain tissues (brainstem is the optimal region). Diagnosis of lyssaviruses in humans is fundamentally different from diagnosis in animals due to the fact that the former most often requires ante-mortem diagnosis while in animals it is usually performed post-mortem (Trimarchi \& Smith 2002). Methods involved in antemortem diagnosis depend on a high level of technical expertise and a well equipped laboratory.

In Africa and other developing regions of the world, lyssavirus diagnostics and surveillance are seriously hampered due to the lack of facilities and logistical support for reliable execution of the FAT. Furthermore, in some instances where a diagnostic facility does exist and is operational, the need to efficiently transport samples to a central facility can often not be met. These obstacles in obtaining a diagnostic result from field specimens have led to serious underreporting of the disease and have ultimately resulted in a lack of commitment to control the disease.

A rapid immunodiagnostic test kit (RIDT) for RABV, that could offer advantages towards overcoming some of the difficulties mentioned above, has been developed (Kang, Oh, Lee, Park, Park, Hong, Lee, Cho \& Song 2007). This lateral flow test uses gold conjugated detector antibodies, including a monoclonal antibody directed against the lyssavirus nucleoprotein. According to Kang et al. (2007), the test is rapid and simple and does not require any specialized equipment or technical expertise-but their study included only gt 1 viruses of which none were of African origin. Since gt 1-4 lyssaviruses occur in Africa, the test should be able to identify all these gts in order to be of any potential use in Africa. It was therefore our aim to evaluate this test for its ability to detect the most diverse isolates within those African lyssavirus gts and variants known to us.

\section{MATERIALS AND METHODS}

\section{Samples}

A total of 25 samples that included 21 diverse representatives of all the African lyssavirus genotypes and four negative controls (Table 1), were tested. Samples were selected based on previous phylogenetic studies to be representative of different phylogenetic groups within each genotype ( $\mathrm{Nel}$ et al. 2005; Sabeta et al. 2007; Cohen, Sartorius, Sabeta, Zulu, Paweska, Mogoswane, Sutton, Nel, Swanepoel, Leman, Grobbelaar, Dayson \& Blumberg 2007; Markotter, Kuzmin, Rupprecht \& Nel 2008).

\section{Fluorescent antibody test (FAT)}

Results were compared with those obtained with the standard fluorescent antibody test (FAT) (Dean et al. 1996) using a polyclonal fluorescein isothiocyanate conjugated immunoglobulin (Onderstepoort Veterinary Institute, OIE Rabies Reference Laboratory).

\section{Rapid immunodiagnostic test (RIDT)}

The RIDT test was performed as described by the manufacturer (Animal Genetics, Inc). Briefly, a $20 \%$ brain suspension of each isolate was prepared in PBS. A swab supplied with the test kit was dipped into the brain homogenate after which it was transferred to the assay diluent for extraction. After 1 min, four drops of the sample were added to the sample well, using the supplied dropper. Final results were read $5 \mathrm{~min}$ after application of the sample. All samples were tested in duplicate. In each case, the appearance of two lines was considered a positive result (one in the test zone and one in the control zone), while the formation of only one line in the control zone was considered negative. Purified monoclonal antibody against the rabies virus nucleoprotein was attached to the test zone and purified goat anti-mouse IgG was attached to the control zone (Kang et al. 2007).

\section{RESULTS}

All 21 samples that tested positive with the FAT also tested positive with the RIDT and all four negative samples tested negative (Table 1 and Fig. 1). Although the intensity of the test lines was found to vary between different virus samples, all the tests were clearly readable and there were no cases of doubtful interpretation. Most samples reacted after about 2 min and none of the samples indicated any 
W. MARKOTTER et al.

TABLE 1 List of lyssavirus-positive samples included in the evaluation of the specificity of the rapid immunodiagnostic test (RIDT) against African lyssaviruses*

\begin{tabular}{|c|c|c|c|c|c|c|c|}
\hline $\begin{array}{l}\text { Sample } \\
\text { number }\end{array}$ & Genotype & Host & Sample & $\begin{array}{l}\text { Laboratory } \\
\text { identification } \\
\text { number }\end{array}$ & $\begin{array}{l}\text { Year of } \\
\text { isolation }\end{array}$ & $\begin{array}{l}\text { Geographical } \\
\text { origin }\end{array}$ & Reference \\
\hline 1 & $\begin{array}{l}\text { Gt } 1 \\
\text { (Canine } \\
\text { biotype) }\end{array}$ & Canine & $\begin{array}{l}\text { Original } \\
\text { canine } \\
\text { brain }\end{array}$ & $272 / 06$ & 2006 & $\begin{array}{l}\text { South Africa, } \\
\text { Limpopo }\end{array}$ & $\begin{array}{l}\text { Cohen et al. } \\
2007\end{array}$ \\
\hline 2 & $\begin{array}{l}\text { Gt } 1 \\
\text { (Canine } \\
\text { biotype) }\end{array}$ & Canine & $\begin{array}{l}\text { Original } \\
\text { canine } \\
\text { brain }\end{array}$ & $567 / 04$ & 2004 & $\begin{array}{l}\text { South Africa, } \\
\text { KwaZulu Natal }\end{array}$ & $\begin{array}{l}\text { Cohen et al. } \\
2007\end{array}$ \\
\hline 3 & $\begin{array}{l}\text { Gt } 1 \\
\text { (Canine } \\
\text { biotype) }\end{array}$ & Canine & $\begin{array}{l}\text { Original } \\
\text { canine } \\
\text { brain }\end{array}$ & $479 / 96$ & 1996 & $\begin{array}{l}\text { South Africa, } \\
\text { Limpopo }\end{array}$ & $\begin{array}{l}\text { Cohen et al. } \\
2007\end{array}$ \\
\hline 4 & $\begin{array}{l}\text { Gt } 1 \\
\text { (Canine } \\
\text { biotype) }\end{array}$ & $\begin{array}{l}\text { Black-backed } \\
\text { jackal }\end{array}$ & $\begin{array}{l}\text { Original } \\
\text { jackal brain }\end{array}$ & $819 / 05$ & 2005 & $\begin{array}{l}\text { South Africa, } \\
\text { North West } \\
\text { Province }\end{array}$ & $\begin{array}{l}\text { Cohen et al. } \\
2007\end{array}$ \\
\hline 5 & $\begin{array}{l}\text { Gt } 1 \\
\text { (Canine } \\
\text { biotype) }\end{array}$ & Bat-eared fox & $\begin{array}{l}\text { Original } \\
\text { bat-eared } \\
\text { fox brain }\end{array}$ & $31 / 05$ & 2005 & $\begin{array}{l}\text { South Africa, } \\
\text { Eastern Cape }\end{array}$ & $\begin{array}{l}\text { Cohen et al. } \\
2007\end{array}$ \\
\hline 6 & $\begin{array}{l}\text { Gt } 1 \\
\text { (Mongoose } \\
\text { biotype) }\end{array}$ & $\begin{array}{l}\text { Galerella } \\
\text { sanguinea }\end{array}$ & $\begin{array}{l}\text { Original } \\
\text { mongoose } \\
\text { brain }\end{array}$ & 22107 & 1994 & Zimbabwe & $\begin{array}{l}\text { Nel et al. } \\
2005\end{array}$ \\
\hline 7 & $\begin{array}{l}\text { Gt } 1 \\
\text { (Mongoose } \\
\text { biotype) }\end{array}$ & $\begin{array}{l}\text { Cynictis } \\
\text { penicillata }\end{array}$ & $\begin{array}{l}\text { Original } \\
\text { mongoose } \\
\text { brain }\end{array}$ & $669 / 90$ & 1990 & $\begin{array}{l}\text { South Africa, } \\
\text { Mpumalanga }\end{array}$ & $\begin{array}{l}\text { Nel et al. } \\
2005\end{array}$ \\
\hline 8 & $\begin{array}{l}\text { Gt } 1 \\
\text { (Mongoose } \\
\text { biotype) }\end{array}$ & $\begin{array}{l}\text { Cynictis } \\
\text { penicillata }\end{array}$ & $\begin{array}{l}\text { Original } \\
\text { mongoose } \\
\text { brain }\end{array}$ & $767 / 95$ & 1995 & $\begin{array}{l}\text { South Africa, } \\
\text { Free State }\end{array}$ & $\begin{array}{l}\text { Nel et al. } \\
2005\end{array}$ \\
\hline 9 & $\begin{array}{l}\text { Gt } 1 \\
\text { (Mongoose } \\
\text { biotype) }\end{array}$ & $\begin{array}{l}\text { Cynictis } \\
\text { penicillata }\end{array}$ & $\begin{array}{l}\text { Original } \\
\text { mongoose } \\
\text { brain }\end{array}$ & $364 / 96$ & 1996 & $\begin{array}{l}\text { South Africa, } \\
\text { Eastern Cape }\end{array}$ & $\begin{array}{l}\text { Nel et al. } \\
2005\end{array}$ \\
\hline 10 & $\begin{array}{l}\text { Gt } 1 \\
\text { (Mongoose } \\
\text { biotype) }\end{array}$ & $\begin{array}{l}\text { Atilax } \\
\text { paludinossus }\end{array}$ & $\begin{array}{l}\text { Original } \\
\text { mongoose } \\
\text { brain }\end{array}$ & $113 / 91$ & 1991 & $\begin{array}{l}\text { South Africa, } \\
\text { Western Cape }\end{array}$ & $\begin{array}{l}\text { Nel et al. } \\
2005\end{array}$ \\
\hline 11 & $\begin{array}{l}\text { Gt } 2 \\
\text { (Lineage A) }\end{array}$ & $\begin{array}{l}\text { Bat } \\
\text { (Epomophorus } \\
\text { wahlbergi) }\end{array}$ & $\begin{array}{l}\text { Original bat } \\
\text { brain }\end{array}$ & LBVSA2008 & 2008 & South Africa & Unpublished \\
\hline 12 & $\begin{array}{l}\text { Gt } 2 \\
\text { (Lineage A) }\end{array}$ & $\begin{array}{l}\text { Bat (Rousettus } \\
\text { aegyptiacus) }\end{array}$ & $\begin{array}{l}\text { Suckling } \\
\text { mouse } \\
\text { brain }\end{array}$ & LBVAFR1999 & 1999 & Senegal & $\begin{array}{l}\text { Markotter et } \\
\text { al. } 2008\end{array}$ \\
\hline 13 & $\begin{array}{l}\text { Gt } 2 \\
\text { (Lineage B) }\end{array}$ & $\begin{array}{l}\text { Bat (Eidolon } \\
\text { helvum) }\end{array}$ & $\begin{array}{l}\text { Suckling } \\
\text { mouse } \\
\text { brain }\end{array}$ & LBVNIG1956 & 1956 & Nigeria & $\begin{array}{l}\text { Markotter et } \\
\text { al. } 2008\end{array}$ \\
\hline 14 & $\begin{array}{l}\text { Gt } 2 \\
\text { (Lineage C) }\end{array}$ & $\begin{array}{l}\text { Mongoose } \\
\text { (Atilax } \\
\text { paludinossus) }\end{array}$ & $\begin{array}{l}\text { Suckling } \\
\text { mouse } \\
\text { brain }\end{array}$ & $\begin{array}{l}\text { LBVMongoose } \\
2004\end{array}$ & 2004 & South Africa & $\begin{array}{l}\text { Markotter et } \\
\text { al. } 2008\end{array}$ \\
\hline 15 & Gt 3 & Feline & $\begin{array}{l}\text { Suckling } \\
\text { mouse } \\
\text { brain }\end{array}$ & 12341 & 1981 & Zimbabwe & $\begin{array}{l}\text { Sabeta et al. } \\
2007\end{array}$ \\
\hline 16 & Gt 3 & Feline & $\begin{array}{l}\text { Suckling } \\
\text { mouse } \\
\text { brain }\end{array}$ & $543 / 95$ & 1995 & $\begin{array}{l}\text { South Africa, } \\
\text { East London }\end{array}$ & $\begin{array}{l}\text { Sabeta et al. } \\
2007\end{array}$ \\
\hline
\end{tabular}


Evaluation of immunodiagnostic test kit for detection of African lyssaviruses from brain material

\begin{tabular}{|c|c|c|c|c|c|c|c|}
\hline $\begin{array}{l}\text { Sample } \\
\text { number }\end{array}$ & Genotype & Host & Sample & $\begin{array}{l}\text { Laboratory } \\
\text { identification } \\
\text { number }\end{array}$ & $\begin{array}{l}\text { Year of } \\
\text { isolation }\end{array}$ & $\begin{array}{l}\text { Geographical } \\
\text { origin }\end{array}$ & Reference \\
\hline 17 & Gt 3 & Feline & $\begin{array}{l}\text { Suckling } \\
\text { mouse } \\
\text { brain }\end{array}$ & $97 / 252$ & 1997 & $\begin{array}{l}\text { South Africa, } \\
\text { Pietermaritzburg }\end{array}$ & $\begin{array}{l}\text { Sabeta et al. } \\
2007\end{array}$ \\
\hline 18 & Gt 3 & Canine & $\begin{array}{l}\text { Suckling } \\
\text { mouse } \\
\text { brain }\end{array}$ & $173 / 06$ & 2006 & South Africa & $\begin{array}{l}\text { Sabeta et al. } \\
2007\end{array}$ \\
\hline 19 & Gt 4 & Human & $\begin{array}{l}\text { Suckling } \\
\text { mouse } \\
\text { brain }\end{array}$ & DUVVSA2006 & 2006 & South Africa & $\begin{array}{l}\text { Paweska et } \\
\text { al. } 2007\end{array}$ \\
\hline 20 & Gt 4 & Bat (unknown) & $\begin{array}{l}\text { Suckling } \\
\text { mouse } \\
\text { brain }\end{array}$ & DUVVSA1981 & 1981 & South Africa & $\begin{array}{l}\text { Paweska et } \\
\text { al. } 2007\end{array}$ \\
\hline 21 & Gt 4 & Human & $\begin{array}{l}\text { Suckling } \\
\text { mouse } \\
\text { brain }\end{array}$ & DUVVSA1970 & 1970 & South Africa & $\begin{array}{l}\text { Paweska et } \\
\text { al. } 2007\end{array}$ \\
\hline
\end{tabular}

* As negative controls, phosphate buffered saline (PBS), uninfected mouse, uninfected canine and uninfected bat brain were used

\section{FIG. 1}

Results of the Rapid immunodiagnostic test (RIDT) after testing negative control samples as well as representatives of African lyssaviruses (Table 1). Samples 1-21 indicate a positive result with different representatives of African lyssaviruses. Negative control samples (PBS, canine and bat uninfected brain) indicated a negative result. $\mathrm{C}=$ control line and $\mathrm{T}=$ test line

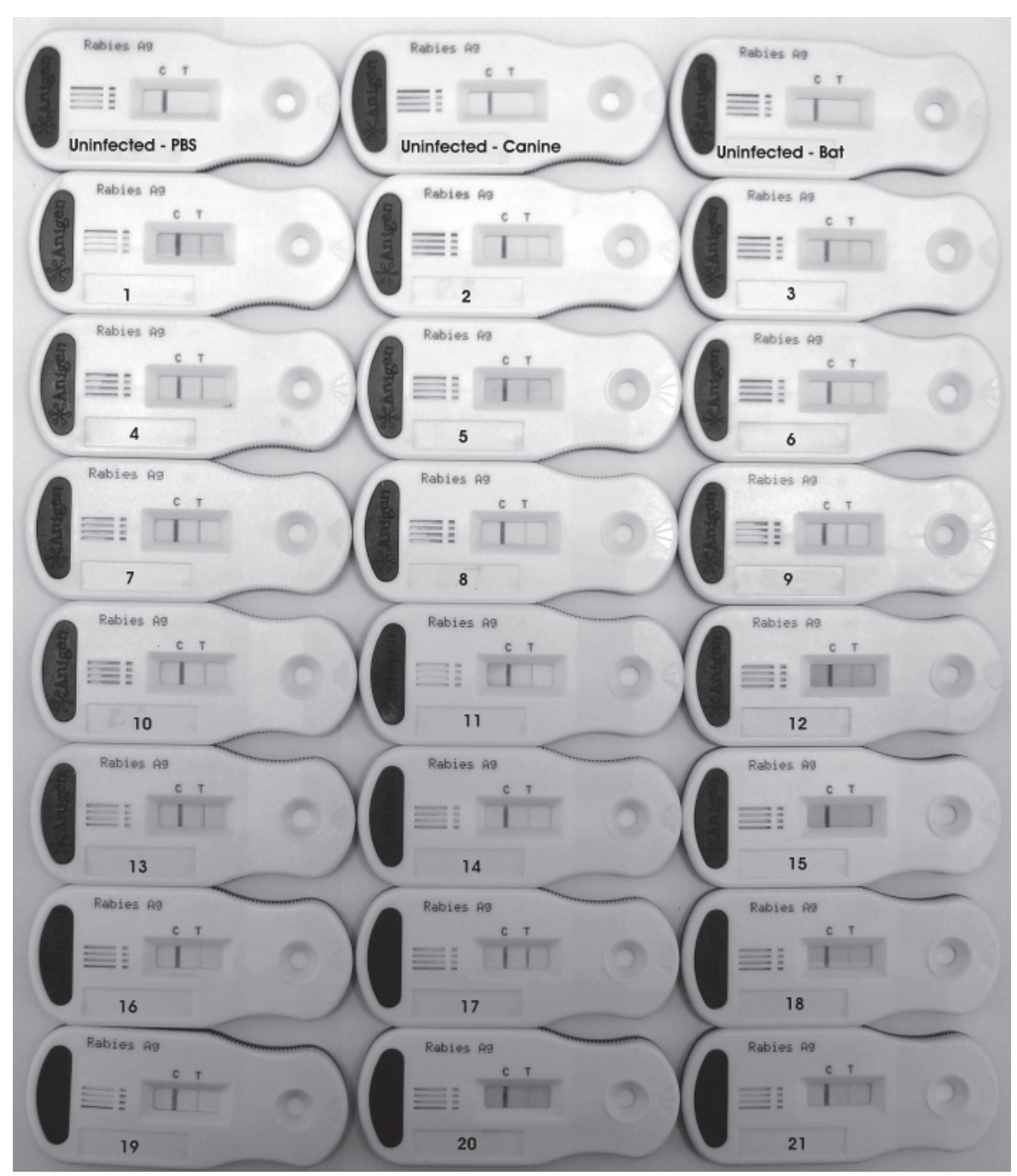


non-specific reactions. No difference in results between field samples and isolates that were passaged in suckling mouse brains was observed.

\section{DISCUSSION}

Rabies is endemic in most developing countries. For most countries in Africa no rigorous epidemiological data for lyssaviruses exist-largely due to the lack of operational rabies diagnostic facilities. The FAT requires a fluorescent microscope, which is not only expensive but needs to be well maintained and is sensitive to power surges and blackouts that are common throughout Africa. Many African governments simply cannot comply with the requirements that would ensure fully competent FAT diagnostics. In other cases, where a diagnostic facility may exist, its usefulness is restricted to specific geographic locations and samples from remote areas seldomly or never reach these laboratories. Under these circumstances, the RIDT may be a useful tool-in our hands it has demonstrated a high specificity (100\%) against representatives of all the known African lyssavirus genotypes when compared to the FAT. This is a very simple test that can be performed in less than 10 min without any specialized equipment, infrastructure, or high level of training. There are no critical points to field use such as cold storage, since the test kit contains everything required for the diagnosis and is stable at ambient temperatures. As indicated in another evaluation of the test, it is capable of detecting low amounts of virus - at an excellent level of sensitivity (slightly less sensitive than a well executed FAT) (Kang et al. 2007). In our hands, several field isolates were examined, including a gt 2 infected bat brain, and all field isolates were detected as positive using the RIDT. From these results, the RIDT could be a very useful additional tool in field surveillance for lyssavirus infections in those many areas where no other diagnostic method is available or where samples simply cannot easily reach a diagnostic laboratory due to logistical and infrastructural limitations. In these latter scenarios, suspect rabies cases are simply not tested at all (personal observations at several locations in Africa). The RIDT could specifically assist in better understanding of the epidemiology of lyssavirus infections in wildlife if application in an on-site manner is considered. Just one example applies to kudu (Tragelaphus strepsiceros) antelope, in which rabies is, in fact, a significant, but still fairly unqualified problem in Namibia and potentially elsewhere. Areas of wildlife reserve are often very remote, and it is rarely possible for conserva- tionists, game rangers or farmers to duly collect and send samples to a diagnostic laboratory for testing.

Brain material is required for the RIDT and where no adequate necropsy facilities are available, other methods for removal of brain material without the risk of opening the scull, could be applied-including, for example, a trucut needle biopsy through superior orbital fissure (Tong, Leung, Lee \& Lam 1999). It must be stressed that a reliable rabies diagnosis can only be made post-mortem using brain material and that saliva must not be recommended. The simplicity of the RIDT kit also urges us to point out a further area of caution: All personnel performing the test should be vaccinated against rabies and trained to follow the safety regulations and procedures for working with lyssaviruses, and in cases of clear potential human exposures, positive diagnosis should be considered as a matter of course while additional testing by FAT should be sought as a matter of urgency. In conclusion, we do not argue that the RIDT should be used as replacement for the well accepted gold standard FAT. In fact, the preferential use of the FAT should be encouraged and implemented wherever possible. We do, however, consider that the RIDT could be a useful onsite test under field conditions and in developing countries with limited diagnostic resources. The technique has the potential of enhancing epidemiological surveillance of lyssaviruses under such conditions and in remote areas where lyssaviruses infections otherwise go unnoticed or unquantified. After the diagnosis samples can also be stored in phosphate-buffered $50 \%$ glycerol saline and stored at $4{ }^{\circ} \mathrm{C}$, or can be kept at room temperature for up to 4 months for future characterization, if needed. In this regard the RIDT, together with a renewed global focus on rabies as one of the most seriously neglected zoonoses, may assist in obtaining at least some rabies epidemiological information from those many parts of Africa that report rabies haphazardly or not at all.

\section{ACKNOWLEDGEMENTS}

We thank Animal Genetics, Inc who supplied the Rapid Immunodiagnostic kits for this study.

\section{REFERENCES}

COHEN, C., SARTORIUS, B., SABETA, C., ZULU, G., PAWESKA, J., MOGOSWANE, M., SUTTON, C., NEL, L., SWANEPOEL, R., LEMAN, P.A., GROBBELAAR, A.A., DYASON, E. \& BLUMBERG, L. 2007. Epidemiology and viral molecular virus characterization of reemerging rabies, South Africa. Emerging Infetcious Diseases, 3:1879-1886. 
DEAN, D.J., ABELSETH, M.K. \& ATANASIU, P. 1996. The fluorescent antibody test, in Laboratory techniques in rabies, edited by F.X. Meslin, M.M. Kaplan \& H. Koprowski. Geneva: World Health Organization.

KANG, B., OH, J., LEE, C., PARK, B., PARK, Y., HONG, K., LEE, K., CHO, B. \& SONG, D. 2007. Evaluation of a rapid immunodiagnostic test kit for rabies virus. Journal of Virological Methods, 145:30-36.

KUZMIN, I.V., NIEZGODA, M., FRANKA, R., AGWANDA, B., MARKOTTER, W., BEAGLEY, J.C., URAZOVA, O.Y., BREIMAN, R.F. \& RUPPRECHT, C.E. 2008. Lagos bat virus in Kenya. Journal of Clinical Microbiology, 46:1451-1461.

MARKOTTER, W., KUZMIN, I., RUPPRECHT, C.E., RANDLES, J., SABETA, C.T., WANDELER, A.I. \& NEL, L.H. 2006a. Isolation of Lagos bat virus from water mongoose. Emerging Infectious Diseases, 12:1913-1918.

MARKOTTER, W., KUZMIN, I., RUPPRECHT, C.E. \& NEL, L.H. 2008. Phylogeny of Lagos bat virus: Challenges for lyssavirus taxonomy. Virus Research, 135:10-21.

MARKOTTER, W., RANDLES, J., RUPPRECHT, C.E., SABETA, C.T., WANDELER, A.I., TAYLOR, P.J. \& NEL, L.H. 2006b. Recent Lagos bat virus isolations from bats (suborder Megachiroptera) in South Africa. Emerging Infectious Diseases, 12:504-506.

NEL, L.H. \& MARKOTTER, W. 2007. Lyssaviruses. Critical Reviews in Microbiology, 33: 301-324.

NEL, L.H., SABETA, C.T., VON TEICHMAN, B., JAFTHA, J.B., RUPPRECHT, C.E. \& BINGHAM, J. 2005. Mongoose rabies in southern Africa: A re-evaluation based on molecular epidemiology. Virus Research, 109:165-73.

PAWESKA, J.T., BLUMBERG, L., LIEBENBERG, C., HEWLETT, R.H., GROBBELAAR, A.A., LEMAN, P.A., CROFT, J.E., NEL, L.H., NUTT, L. \& SWANEPOEL, R. 2006. Fatal human infection with rabies-related Duvenhage virus, South Africa. Emerging Infectious Diseases, 12:1965-1967.

SABETA, C.T., MARKOTTER, W., MOHALE, D.K., SHUMBA, W., WANDELER, A.I. \& NEL, L.H. 2007. Recent Mokola virus isolations from domestic mammals in South Africa. Emerging Infectious Diseases, 13:1371-1373.

TONG, R., LEUNG, K.M., LEE, K.C. \& LAM, A.W. 1999. Trucut needle biopsy through superior orbital fissures for rabies diagnosis. The Lancet, 354:2137-2138.

TORDO, N., BENMANSOUR, A. \& CALISHER, C. et al. 2004. Virus taxonomy: The classification and nomenclature of viruses, in The eight report of the International Committee on Taxonomy of Viruses, edited by C.M. Fauquet, M.A. Mayo, J. Maniloff, U. Desselberger \& L.A. Ball. London: Elsevier/Academic Press.

TRIMARCHI, C.V. \& SMITH, J.S. 2002. Diagnostic evaluation in rabies, edited by A.C. Jackson \& W.H. Wunner. London: Elsevier Science.

VON TEICHMAN, B.F., THOMSON, G.R., MEREDITH, C.D. \& NEL, L.H. 1995. Molecular epidemiology of rabies virus in South Africa: evidence for two distinct virus groups. Journal of General Vorology, 76:73-82.

WHO 2005. Expert consultation on rabies. Geneva: World Health Organization (Technical Report Series, 931). 